\title{
EFFECT OF BLOOD PROTEASE AND TRYPSIN INHIBITOR ON THE CLOTTING MECHANISM ${ }^{1}$
}

\author{
By ANTHONY J. GLAZKO \\ (From the Department of Biochemistry, Emory University, Georgia)
}

(Received for publication August 17, 1946)

The influence of proteolytic enzymes on blood coagulation has attracted considerable attention in recent years because of the possibility of their involvement in the normal clotting process. Eagle and Harris (1) showed that certain proteolytic enzymes such as trypsin could activate prothrombin; while other enzymes such as papain could clot fibrinogen directly. Schmitz $(2,3,4)$ claimed that he isolated both trypsin and a specific trypsin-inhibitor from plasma. However, more recent work indicates that the protease is not identical with trypsin, although it is quite similar in many respects $(5,6)$.

It has long been known that proteolytic activity appears in blood following treatment with chloroform, acetone, or certain other denaturing agents. Tagnon and others $(7,8,9)$ used this technic to activate blood protease and described many of its properties. Holmberg (10) and Christensen (11) independently demonstrated that streptokinase, ${ }^{2}$ which is itself devoid of proteolytic activity, could activate the protease in blood and thus produce digestion. Christensen also showed that the blood protease activated by streptokinase was identical with chloroform-activated serum protease (6). The inactive enzyme is located principally in globulin fraction III-2, along with considerable amounts of prothrombin $(12,13)$. Active protease is present in globulin fraction III-3, which is actually a sub-fraction of III-2. Fraction III-3 was used in the present experiments as a convenient source of blood protease.

A definite coagulation-inhibiting effect of crystalline pancreatic trypsin-inhibitor was demon-

1 This work was supported in part by grants from the Life Insurance Medical Research Fund and the University Center in Georgia.

2 Following the suggestion of Christensen (11), it was decided to adopt the term "streptokinase" for use throughout this paper. The earlier designation "streptococcal fibrinolysin" was based on the erroneous assumption that the fibrinolytic enzyme itself was produced in the bacterial culture. strated by Ferguson (14), supporting his thesis that a protease is involved in the activation of prothrombin (15). Similar results were obtained by Grob (16), who also found that serum anti-protease prepared by the method of S.chmitz (4) delayed coagulation. Tagnon and Soulier (17) showed that trypsin-inhibitor isolated from soy bean flour could also inhibit coagulation. Their work has been confirmed and extended by the observations described in this paper.

\section{METHODS AND MATERIALS}

Most of the experiments described here involve changes in thrombin concentration which can be measured indirectly by means of the clotting time (18). In all cases, solutions were maintained at $38^{\circ} \mathrm{C}$., and the $\mathrm{pH}$ was kept in the range of 7.2 to 7.6 as measured with a glass electrode. A small amount of phenyl mercuric borate was added to the reagents to prevent bacterial growth. Tests for thrombic activity were carried out by pipetting $0.5 \mathrm{ml}$. of thrombin into $1 \mathrm{ml}$. of fibrinogen solution, using $10 \mathrm{~mm} . \times 75 \mathrm{~mm}$. serological tubes. Clot formation was timed from the moment of addition of thrombin or, in the case of plasma, from the moment of recalcification, and the tubes were tilted once each second until the first signs of clotting were observed.

Plasma: Whole blood was collected from dogs under nembutal anaesthesia into paraffined bottles containing $1 / 10$ volume of 3.8 per cent sodium citrate solution. The blood was centrifuged at 1,800 r.p.m. for 30 minutes, and the plasma was siphoned off and re-centrifuged in a high speed angle centrifuge. The plasma was then filtered through a sintered glass disc and kept refrigerated until used.

Buffered saline: $\mathrm{M} / 100$ phosphate at $\mathrm{pH} 7.4$ was made up in 0.5 per cent saline.

Fibrinogen: Fibrinogen was prepared by several precipitations with quarter-saturated ammonium sulfate, the final precipitate being dried under vacuum over $\mathrm{P}_{2} \mathrm{O}_{5}$; 0.15 per cent solutions were made up in buffered saline as needed. The dry powder was stable for over 3 months when kept in the ice box. All fibrinogen solutions were routinely tested for absence of prothrombin by the addition of calcium chloride and thromboplastin.

Calcium chloride: A $1 \mathrm{M}$ stock solution of $\mathrm{CaCl}_{2}$ was diluted to $M / 10$ each day as required.

Thromboplastin: Dog brain washed free of blood was macerated in saline, and the extract was preserved by freezing storage. Tests were made for prothrombin by 
the addition of calcium chloride; they were found to be negative.

Prothrombin: The prothrombin was prepared by the acetone precipitation method of Howell (19).

Thrombin: Unless otherwise specified, Lederle's Hemostatic Clotting Globulin diluted 1:10 with buffered saline was used as the source of thrombin.

Soy trypsin-inhibitor: A crystalline preparation of soy trypsin-inhibitor ${ }^{3}$ was dissolved in buffered saline to give a solution containing $1 \mathrm{mgm}$. per $\mathrm{ml}$. This was diluted as required.

Globulin fraction III-3: This alcohol-precipitated fraction 4 contains a protease which is unstable in aqueous solution. Therefore, the dry material was weighed out on an analytical balance and dissolved in saline just before use.

\section{RESULTS}

\section{A. Effect of soy trypsin-inhibitor on the clotting time of recalcified plasma}

The relation of clotting time to concentration of inhibitor was studied by recalcifying citrated plasma in the presence of excess thromboplastin and different quantities of crystalline soy trypsininhibitor. One milliliter dilutions of inhibitor in saline were added to 1-ml. portions of plasma, fol-

${ }^{3}$ Crystalline soy trypsin-inhibitor was obtained through the courtesy of Dr. Moses Kunitz.

4 This protein fraction was obtained through the courtesy of Dr. John T. Edsall. It was prepared under a contract between the Office of Scientific Research and Development and Harvard University from human blood collected by the American Red Cross. lowed by the addition of $0.5 \mathrm{ml}$. thromboplastin and $0.5 \mathrm{ml}$. of $\mathrm{M} / 10$ calcium chloride. The results presented in Figure 1 show that the increase in clotting time is directly proportional to the concentration of inhibitor in plasma over the range of concentrations used. We have adopted this technic for the rapid assay of inhibitor in various stages of purification by comparing the effect on clotting time with that produced by standard crystalline inhibitor preparations.

\section{B. Absence of effect of inhibitor on the second phase of coagulation}

Various concentrations of inhibitor were made up by serial dilution in saline and added in $0.5-\mathrm{ml}$. quantities to $0.5-\mathrm{ml}$. portions of plasma and fibrinogen solutions. These mixtures were warmed to $38^{\circ} \mathrm{C}$. and clotted by the addition of $0.5-\mathrm{ml}$. thrombin. The clotting times presented in Table I show no inhibitory effect whatsoever, confirming

TABLE I

Effect of inhibitor on the second phase of coagulation

\begin{tabular}{l|c|c|c|c|c|c}
\hline \hline Inhibitor (micrograms) & 0 & 31 & 62 & 125 & 250 & 500 \\
\hline $\begin{array}{l}\text { Plasma clotting time } \\
\text { (seconds) }\end{array}$ & $11^{\prime \prime}$ & $11^{\prime \prime}$ & $11^{\prime \prime}$ & $11^{\prime \prime}$ & $11^{\prime \prime}$ & $11^{\prime \prime}$ \\
$\begin{array}{c}\text { Fibrinogen clotting time } \\
\text { (seconds) }\end{array}$ & $15^{\prime \prime}$ & $14^{\prime \prime}$ & $14^{\prime \prime}$ & $14^{\prime \prime}$ & $13^{\prime \prime}$ & $13^{\prime \prime}$ \\
\hline
\end{tabular}

Test mixture: ${ }_{2}^{\top} 0.5 】 \mathrm{ml}$. plasma $+[0.5] \mathrm{ml} .[$ inhibitor +0.5 ml. thrombin.

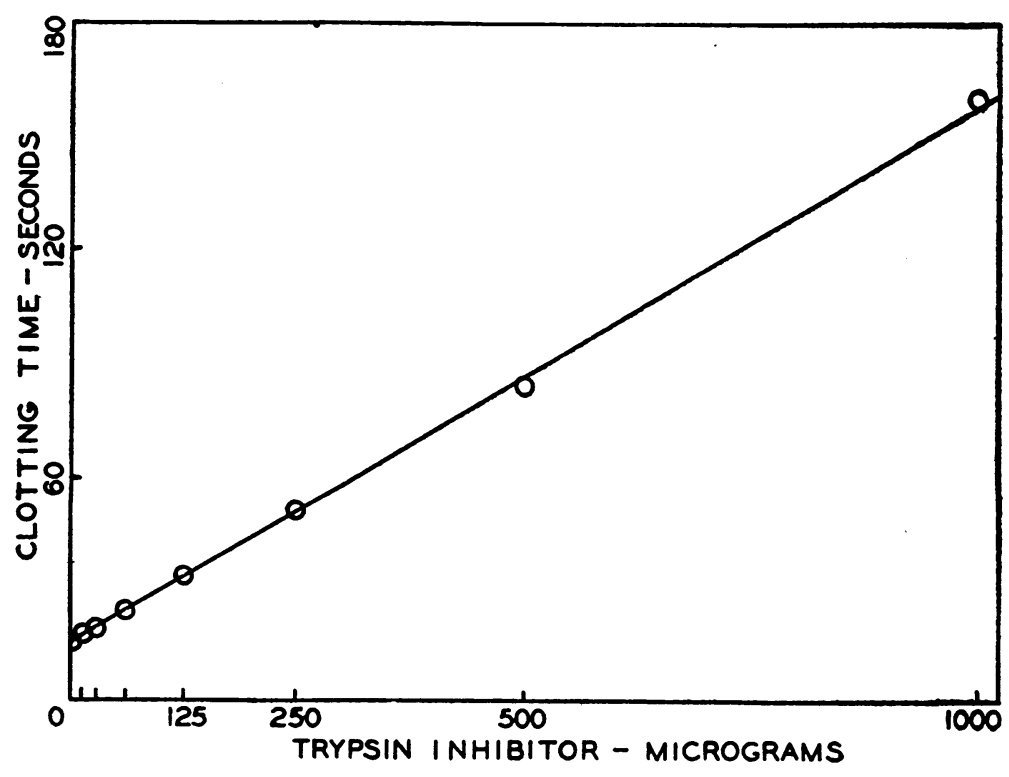

FIG. 1. 
the observations of Tagnon and Soulier (17). The absence of inhibition in plasma minimizes the possibility that an albumin co-factor is required for the second-phase action of trypsin-inhibitor (14).

\section{Effect of inhibitor on the activation of pro- thrombin}

Our attention was next directed to the first phase of coagulation, which normally results in the formation of thrombin. Serial dilutions of inhibitor were made in 1-ml. volumes of buffered saline, and $3 \mathrm{ml}$. of prothrombin solution was added to each. The mixtures were warmed to $38^{\circ} \mathrm{C}$. and activated by the addition of $0.5-\mathrm{ml}$. quantities of thromboplastin and calcium chloride solutions. After standing for different periods of time, the mixtures were tested for thrombic activity by the addition of $0.5-\mathrm{ml}$. portions to $1 \mathrm{ml}$. of fibrinogen solution. The clotting times are presented in Figure 2, from which the following observations are made:

(a) The minimum clotting times, indicating maximum concentrations of thrombin, were fairly uniform with low concentrations of inhibitor but showed a marked increase at higher concentrations. The activation time required for maximum thrombin formation was also greater with higher concentrations of inhibitor. (b) The rate of thrombin disappearance increased markedly with higher concentrations of inhibitor. This does not necessarily mean an increased rate of thrombinolysis, since Glazko and Ferguson (18) demonstated that a constant rate of thrombin inactivation produced an increase in clotting time which varied inversely with thrombin concentration. The implication is that the rapid increase in clotting time is apparent only because of the small amount of thrombin formed in the presence of inhibitor. An experiment in which $200 \mu \mathrm{g}$. of soy inhibitor was added to $1 \mathrm{ml}$. of thrombin produced no significant changes in thrombic activity over a period of 18 hours at $38^{\circ}$ C., showing that the presence of inhibitor per se had no influence on the rate of thrombin disappearance.

\section{The effect of the concentration of prothrombin and thromboplastin on the action of in- hibitor}

An attempt was made to determine whether the action of trypsin-inhibitor was influenced by variations in the concentration of prothrombin and thromboplastin. Since it has been reported (7) that blood protease is inhibited by prothrombin, especially in the presence of thromboplastin, it was thought that changes in the concentration of these

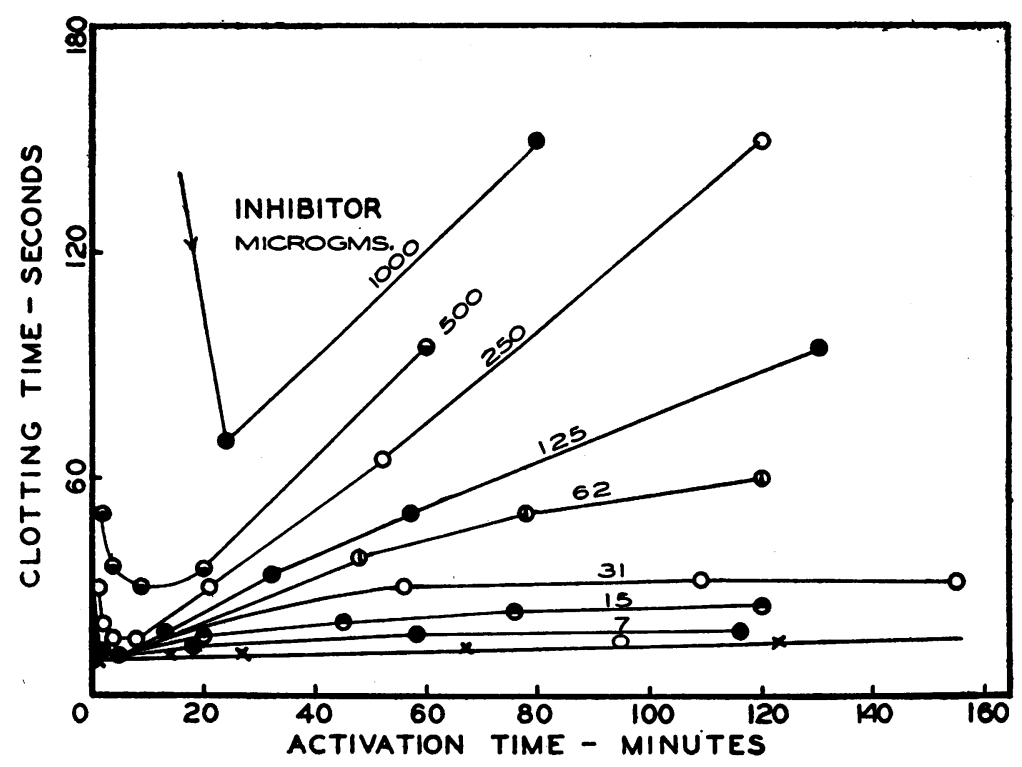

FIG. 2. 
factors might produce an exaggerated effect in the presence of trypsin-inhibitor.

The clotting time of recalcified plasma was measured at $38^{\circ} \mathrm{C}$. in the presence of soy inhibitor and different concentrations of thromboplastin, as shown in Table II. The range of thromboplastin

TABLE II

Effect of thromboplastin on coagulation of plasma in the presence of inhibitor

\begin{tabular}{c|c|c|c}
\hline \hline \multirow{2}{*}{$\begin{array}{c}\text { Thromboplastin } \\
\text { (relative con- } \\
\text { centration) }\end{array}$} & \multicolumn{3}{|c}{ Soy trypsin-inhibitor (micrograms) } \\
\cline { 2 - 4 } & 0 & 25 & 50 \\
\hline 10,000 & $22^{\prime \prime}$ & $30^{\prime \prime}$ & $43^{\prime \prime}$ \\
1,000 & $21^{\prime \prime}$ & $25^{\prime \prime}$ & $37^{\prime \prime}$ \\
100 & $32^{\prime \prime}$ & $42^{\prime \prime}$ & $58^{\prime \prime}$ \\
10 & $60^{\prime \prime}$ & $75^{\prime \prime}$ & $110^{\prime \prime}$ \\
1 & $170^{\prime \prime}$ & $270^{\prime \prime}$ & $510^{\prime \prime}$ \\
0 & $780^{\prime \prime}$ & $960^{\prime \prime}$ & $1380^{\prime \prime}$ \\
\hline
\end{tabular}

Body of table gives clotting times in seconds.

Test mixtures: $0.5 \mathrm{ml}$. plasma $+0.5 \mathrm{ml}$. thromboplastin $+0.5 \mathrm{ml}$. inhibitor or saline, recalcified with $0.5 \mathrm{ml}$. M/10 $\mathrm{CaCl}_{2}$.

concentration extended from that of the stock preparation to a dilution of 1 in 10,000 . In all cases, the presence of soy inhibitor produced about the same proportional inhibition with low concentrations as with larger amounts. The results presented in Table III show that sufficient throm-

TABLE III

Effect of prothrombin concentration on thrombin formation in the presence of inhibitor

\begin{tabular}{c|c|c}
\hline \hline $\begin{array}{c}\text { Prothrombin } \\
\text { (Relative concen- } \\
\text { tration) }\end{array}$ & \multicolumn{2}{|c}{ Minimum clotting time (seconds) } \\
\cline { 2 - 3 } & $\begin{array}{c}\text { No inhibitor } \\
\text { added }\end{array}$ & $\begin{array}{c}125 \text { micrograms } \\
\text { inhibitor added }\end{array}$ \\
\hline 80 & $15^{\prime \prime}$ & $21^{\prime \prime}$ \\
8 & $47^{\prime \prime}$ & $54^{\prime \prime}$ \\
4 & $65^{\prime \prime}$ & $105^{\prime \prime}$ \\
2 & $85^{\prime \prime}$ & $240^{\prime \prime}$ \\
1 & $150^{\prime \prime}$ & - \\
\hline
\end{tabular}

Mixture: $3 \mathrm{ml}$. prothrombin dilution $+1 \mathrm{ml}$. inhibitor or saline $+0.5 \mathrm{ml}$ : thromboplastin $+0.5 \mathrm{ml}$. $\mathrm{M} / 10 \mathrm{CaCl}_{2}$.

bin was produced for reliable clotting tests in a maximum prothrombin dilution of only $1: 80$, under the particular experimental conditions used. The clotting times given are the minimum values observed during the activation process. Here again, the decreased concentration of prothrombin did not appear to enhance the inhibitory effect of trypsin-inhibitor.

\section{E. Effect of inhibitor on blood protease}

The effect of trypsin-inhibitor on blood protease was demonstrated by following the rate of casein digestion in the presence of various concentrations of inhibitor. Globulin fraction III-3 was added to 1 per cent casein (at $\mathrm{pH} 7.4$ ) containing 0,100 , 200 and $400 \mu \mathrm{g}$. of soy trypsin-inhibitor. The mixtures were incubated at $38^{\circ} \mathrm{C}$. and $1-\mathrm{ml}$. samples were taken at intervals for determination of acid-soluble phenols, using 6 per cent trichloracetic acid for precipitation of protein and the Heidelberger modification (20) of the FolinCiocalteu reaction for color development. From the results presented in Table IV it is evident

TABLE IV

Inhibition of blood protease by soy trypsin inhibitor

\begin{tabular}{c|c|c|c|c}
\hline \hline \multirow{2}{*}{$\begin{array}{c}\text { Inhibitor } \\
\text { (micro- }\end{array}$} & \multicolumn{4}{|c}{ Incubation time (hours) } \\
\cline { 2 - 5 } grams) & 0 & 1 & 4 & 16 \\
\hline 0 & 0 & 27 & 43 & 62 \\
100 & 0 & 8 & 17 & 30 \\
200 & 0 & 3 & 10 & 14 \\
400 & 0 & 0 & 7 & 9 \\
$0^{*}$ & 0 & 0 & 0 & 0 \\
\hline
\end{tabular}

* No enzyme added.

Body of table expresses tyrosine equivalent in terms of $\mu \xi$ per $\mathrm{ml}$.

Digestion mixture: $10 \mathrm{ml} .1$ per cent casein $+4 \mathrm{ml}$. inhibitor dilution $+1 \mathrm{ml}$. ( $=10 \mathrm{mgm}$.) globulin III -3 solution.

that the degree of inhibition was proportional to the concentration of soy trypsin-inhibitor in the digestion mixtures. This is in agreement with the results observed with trypsin-inhibitor obtained from pancreas and from serum $(4,6,16)$.

\section{F. Thrombin activity of globulin fraction $I I I-3$}

Thrombic activity was found to appear in aqueous solutions of globulin fraction III-3 in the absence of any added calcium or thromboplastin, as shown by the data in Table V. This experiment was performed in the presence of sufficient citrate to eliminate the effect of the small amount of calcium present, which was found to be about $2.5 \mu \mathrm{g}$. per mgm. of globulin.

It was first thought that the results were due to the direct activation of prothrombin in the globulin fraction by the protease, but similar results were also obtained in the presence of sufficient trypsin-inhibitor to stop the action of the 
TABLE $V$

Thrombin formation by globulin fraction III-3

\begin{tabular}{l|l|l|l|l|l|l|l|l|l}
\hline \hline $\begin{array}{c}\text { Incubation time } \\
\text { (minutes) }\end{array}$ & 0 & $1^{\prime}$ & $2^{\prime}$ & $3^{\prime}$ & $5^{\prime}$ & $10^{\prime}$ & $30^{\prime}$ & $70^{\prime}$ & $330^{\prime}$ \\
\hline $\begin{array}{c}\text { Clotting time } \\
\text { (seconds) }\end{array}$ & - & - & $44^{\prime \prime}$ & $40^{\prime \prime}$ & $39^{\prime \prime}$ & $34^{\prime \prime}$ & $32^{\prime \prime}$ & $35^{\prime \prime}$ & $42^{\prime \prime}$ \\
\hline
\end{tabular}

$10 \mathrm{mgm}$. globulin was dissolved in $5 \mathrm{ml}$. saline containing 0.38 per cent sodium citrate. Thrombic activity was measured after different periods of incubation at $38^{\circ} \mathrm{C}$. by the addition of $0.5 \mathrm{ml}$. to $1.0 \mathrm{ml}$. fibrinogen.

protease. Therefore, it seems likely that the appearance of thrombin in the solution was not due to the activation of prothrombin, but to some other mechanism involving the presence of pre-formed thrombin.

\section{DISCUSSION}

The experiments presented here show that crystalline soy trypsin-inhibitor interferes with the activity of the protease in globulin fraction III-3 and also inhibits the activation of prothrombin. There is a good possibility that these observations are dependent on the same process, namely inhibition of proteolytic activity. The activation of prothrombin may be dependent on the presence of active protease, although we have no proof for this as yet. There is good evidence that the protease in blood is not pancreatic trypsin $(5,6)$, although it is similar in many respects. Tagnon (7) has already indicated that the blood protease can activate prothrombin in the absence of calcium, but his observations have not been confirmed.

Ionic calcium and thromboplastin are unquestionably involved in the normal activation of prothrombin, but their precise functions are still unknown. It is suggested that calcium may be necessary for the activation of blood protease, just as it produces an increased yield of trypsin in the autocatalytic activation of trypsinogen (21). The protease might then function in the activation of prothrombin.

Blood protease and prothrombin are closely associated in many respects. Prothrombin has been reported to inhibit the proteolytic action of chloroform-treated plasma (7). Both prothrombin and inactive protease are present in globulin fraction III-2 $(12,13)$, while active thrombin and active protease are present in globulin fraction III-3 (see sections $E$ and $F$ ). These relations are so striking that they merit further investigation. Some evidence indicates that thrombin itself is proteolytic (22), but the best preparations of thrombin made to date have no demonstrable fibrinolytic activity (23). The ultimate solution of this problem seems to depend on the preparation of pure crystalline thrombin and blood protease.

\section{SUMMARY}

1. The anticoagulant action of crystalline soy trypsin-inhibitor is due to interference with the thrombin-forming mechanism. No effects were observed on the second phase of coagulation.

2. The rate of thrombin formation and also the maximum amount of thrombin produced were diminished in the presence of inhibitor.

3. The increase in clotting time of recalcified plasma was found to be directly proportional to the concentration of inhibitor.

\section{BIBLIOGRAPHY}

1. Eagle, H., and Harris, T. N., The coagulation of blood by proteolytic enzymes. J. Gen. Physiol., 1937, 20, 543.

2. Schmitz, A., Uber die Proteinase des Fibrins. Ztschr. Physiol. Chem., 1936, 244, 89.

3. Schmitz, A., Uber die freilegung von aktivem Trypsin aus Blutplasma. Ztschr. f. Physiol. Chem., 1937, 250, 37.

4. Schmitz, A., Uber den Trypsin-Inhibitor des Blutes. Ztschr. f. Physiol. Chem., 1938, 255, 234.

5. Kaplan, M. H., Studies on streptococcal fibrinolysis: I. Dissimilarity of serum protease and trypsin as indicated by separate specificities of their kinases, fibrinolysin and enterokinase. J. Clin. Invest., 1946, 25, 331 .

6. Christensen, L. R., and MacLeod, C. M., A proteolytic enzyme of serum: characterization, activation, and reaction with inhibitors. J. Gen. Physiol., 1945, 28, 559.

7. Tagnon, H. J., The significance of fibrinolysis in mechanism of coagulation of plood. J. Lab. \& Clin. Med., 1942, 27, 1119.

8. Tagnon, H. J., Davidson, C. S., and Taylor, F. H. L., Studies on blood coagulation: a proteolytic enzyme prepared from calcium and platelet free normal human blood plasma. J. Clin. Invest., 1942, 21, 525.

9. Kaplan, M. H., Tagnon, H. J., Davidson, C. S., and Taylor, F. H. L., Studies on blood coagulation: the nature and properties of a proteolytic enzyme derived from plasma. J. Clin. Invest., 1942, 21 , 533. 
10. Holmberg, C. G., Cleavage of fibrin by streptococcal fibrinolysin. Arkiv Kemi, Mineral., Geol., 1944, 17 A, No. 28.

11. Christensen, L. R., Streptococcal fibrinolysis : A proteolytic reaction due to a serum enzyme activated by streptococcal fibrinolysin. J. Gen. Physiol., 1945, 28, 363.

12. Edsall, J. T., Ferry, R. M., and Armstrong, S. H., Jr., Clinical, chemical, and immunological studies on the products of human plasma fractionation: XV. The proteins concerned in the blood coagulation mechanism. J. Clin. Invest., 1944, 23, 557.

13. Taylor, F. H. L., Davidson, C. S., Tagnon, H. J., Adams, M. A., MacDonald, A. H., and Minot, G. R., Studies in blood coagulation: the coagulation properties of certain globulin fractions of normal human plasma in vitro. J. Clin. Invest., 1945, 24, 698.

14. Ferguson, J. H., Crystalline trypsin-inhibitor and blood clotting. Proc. Soc. Exper. Biol. \& Med., 1942, 51, 373.

15. Ferguson, J. H., A new blood-clotting theory. Science, 1943, 97, 319.

16. Grob, D., The antiproteolytic activity of serum: II.
Physiological significance. The influence of purified trypsin inhibitor on the coagulation of blood. J. Gen. Physiol., 1943, 26, 423.

17. Tagnon, H. J., and Soulier, J. P., Anticoagulant activity of the trypsin inhibitor from soy bean flour. Proc. Soc. Exper. Biol. \& Med., 1946, 61, 440.

18. Glazko, A. J., and Ferguson, J. H., Kinetics of thrombin inactivation as influenced by physical conditions, trypsin and serum. J. Gen. Physiol., 1940, 24, 169.

19. Howell, W. H., Prothrombin. Am. J. Physiol., 1914, 35, 474.

20. Heidelberger, M., and MacPherson, C. F. C., Quantitative micro-estimation of antibodies in the sera of man and other animals. Science, 1943, 97, 405.

21. MacDonald, M. R., and Kunitz, M., The effect of calcium and other ions on the autocatalytic formation of trypsin from trypsinogen. J. Gen. Physiol., 1941, 25, 53.

22. Presnell, A. K., Thrombin, a proteolytic fibrinogenase. Am. J. Physiol., 1938, 122, 596.

23. Seegers, W. H., Purification of prothrombin and thrombin: chemical properties of purified preparations. J. Biol. Chem., 1940, 136, 103. 